\title{
Educating Engineering Students in the Arts
}

\author{
Ken Tallman \\ Engineering Communication Program, University of Toronto \\ k.tallman@utoronto.ca
}

\begin{abstract}
The presentation will discuss a third-year engineering elective course, Engineering and Science in the Arts, offered by the Faculty of Applied Science and Engineering at the University of Toronto. The presentation will detail the unique course deliverables, which require the engineering students to, first, create original works of art, and, secondly, to explain how these works connect to engineering and/or science. A key objective in the course was that the students eradicate the boundaries separating engineers and artists, and this presentation will consider the course's success in this regard.
\end{abstract}

Keywords: Arts, engineering, undergraduate engineering education, creativity

\section{BACKGROUND}

The elective course, Engineering and Science in the Arts, offered at the University of Toronto for the first time in Fall 2012, intended that undergraduate engineering students have the opportunity to advance their understanding of and practice in creativity within a new context. Rather than working on an engineering design project or solving a real-world problem, the students were asked to create a work of art that, in some manner, was connected to engineering and/or science.

Students were free to choose the type of artwork they wanted to create. Some created sculptures, some created photographs, some created musical compositions, and one created an animated movie. The only requirement beyond creating a work of art was that they present their works to the class and explain their works' connections to engineering and/or science and their works' connections to selected art theory studied in the course.

The course had a small enrollment of 12 students, with most students in their third or fourth year of study. They came into the course with limited knowledge of the arts. Though many had knowledge of music, some having trained to play at least one instrument, few had knowledge of or practice in other artistic mediums, such as painting, sculpture, or theatre.

\section{COURSE OBJECTIVES}

A key objective in the course was that it direct students toward a new and more sophisticated understanding of creativity. When entering the course, students had a fairly narrow understanding of creativity, connecting it primarily to utility and usefulness. Following a tradition in engineering thought and practice, students assumed that creative endeavors should aim to make a useful contribution to society. They discovered, however, that artists and art theorists, particularly those of the modern tradition, have long practiced and interpreted the creative act in very different ways, at times challenging interpretation of any kind. The aesthetic theories of the Surrealists, for example, took aim at the rational and the utilitarian in art, looking beneath everyday experience into the world of the unconscious and dreams for subject matter [1]. Thus, for many students, the learning experience was, largely, one of unlearning. Many preconceptions had to be abandoned before new understandings could emerge.

\section{COURSE OUTCOMES}

As students became aware of and accepted different types of creativity in the works of others, their own works reflected this new freedom. Their works of art didn't necessarily need to "do" something or deliver a specific message. The possibility that creativity could be connected to both the principles of engineering and the aesthetic theories of modern artists allowed for the development of a rich set of skills that the students did not anticipate when they began the course. These skill sets will surely be useful to these students as they move forward in their personal and professional lives.

\section{References}

[1] André Breton, "Surrealist manifesto," Modernism: An Anthology. Ed. L. Rainey. Trans. M. Polizzotti. London: Blackwell Publishing, 2005, pp. 718-7. 